\title{
A Phenomenological Investigation into the Problem of Faithfulness in Translation (I)
}

\author{
Wang Dong-mei \\ School of Business Management, Henan Institute of Engineering, Zhengzhou 451191, China \\ pingyuanmei686@sina.com
}

\begin{abstract}
As being-in-the-world, human beings not merely have a strong inclination to be ensnared in entities within the world of their circumspective concern in a way in which they can be definite in finding out a fact that who they are is determined by those entities through interpreting themselves in terms of the world of their concern — an ontological light of being in which they concernfully exist

Index Terms - Phenomenological, Faithfulness, Translation
\end{abstract}

\section{Introduction}

At the very beginning of Being and Time, Heidegger has unambiguously laid out the aim of this work is to work out "the question of the meaning of Being and to do so concretely" (BT, 17). Later on page 33, he thinks that he has found the proper point of departure to tackle this problem: namely, to begin with an existential analytics of human beings; or in other words, to begin with an account of the basic structure of human existence, in which the "fundamental ontology, from which alone all other ontologies can take their rise, must be sought" (BT, 34). Why so? Because an existential analytics of human beings can offer the means of "laying bare the horizon for an interpretation of the meaning of Being in general” (BT, 36). For Heidegger, "an analytic of Dasein must remain our first requirement in the question of being” (BT, 37), and the meaning of being has to do specifically with the existence of human beings. At the same time, when the point of departure of tackling the question of the meaning of being is found out, Heidegger has also searched out the proper method to this question, this is what he calls the hermeneutic phenomenology. In Heidegger mind, the existential ontology and the hermeneutic phenomenology are nothing but the two aspects of one thing: "Ontology and phenomenology are not two distinct philosophical disciplines among others. These terms characterize philosophy itself with regard to its object and its way of treating that object" (BT, 62 ). It seems that this methodology of phenomenology is the inherent requirement of the existential-ontological analytics of human beings, for it is none other than the being-ontological conditions of interpretation which asks for something that shows itself in itself, that is, shows itself as such, as it is. Only by this phenomenological ontology, something can be grasped as something, as the thing itself. If the existential analytics of human beings carried out in such a way, it is of course phenomenological, therefore the question of the meaning of being in general is raised not only in terms of being-ontology as the object but also in terms of ontological phenomenology as the method (way): "phenomenological ontology takes its departure from the hermeneutic of Dasein, as an analytic of existence ... and to which it returns" (BT, 62). For this reason, we can argue what Heidegger is interested in is not the particular conducts and understandings, but the universal conditions of possibility of interpretation. Interpretation, for Heidegger, means an explicit understanding, making sense of something as something - primitively entities as entities, that is, as being. According to Heidegger, the question of the meaning of being, the question concerning what we understand when we understand entities as entities, presupposes some general account of our ability to understand anything explicitly as anything. Heidegger phenomenological ontology is in favor of an inquiry into the general conditions of possibility which makes something sensible to us when something is understood as something. Since faithfulness in translation is such a phenomenon of an understanding of being (thing) which is alongside the history of translation, therefore this phenomenon of being can be interpreted in terms of Heidegger phenomenological ontology which, we believe, can provide the fundamental-ontological explanation for it.

\section{The Phenomenon of Faithfulness in Translation as the Being of the Translator}

One irrefutable fact is that the conception of "faithfulness" in the history of translation is primarily raised by the translators who not only minutely experienced the very act of translation but also ever tried to theoretically summarize such experiences in translating. Even though there is an opinion that the phenomenon of translating act is as old as the history of human beings, yet this phenomenon of translation act was nevertheless kept in hiddenness until there emerged such persons we mentioned just now. Here rises a question: by what reason did those translators describe as well as prescribe the act of translation with the rule or criterion of faithfulness (fidelity) at the very beginning when the phenomenon of translation became so conspicuous or circumspectively concernful that it could not escape from those people's horizon any longer? Translating actions, in so far as we know, are nothing special in comparison with human beings' understanding of being as well as its various derivative modes of understanding actions; they are in fact no more than our human beings' intelligible comporting to the kind of being of the entities which are going to be translated within the understood world. In this regard, George Steiner states very clearly: 
After Babel postulates that translation is formally and pragmatically implicit in every act of communication, in the emission and reception of each and every mode of meaning, be it in the widest semiotic sense or in more specifically verbal exchanges. To understand is to decipher. To hear significance is to translate. Thus the essential structural and executive means and problems of the act of translation are fully present in acts of speech, of writing, of pictorial encoding inside any given language. Translation between languages is a particular application of a configuration and model fundamental to human speech even when it is monoglot. ...we 'translate' at every moment when speaking and receiving signals in our own tongue (Steiner, 2004: xii).

It is obvious that Steiner has posited the act of translation on the level of human beings' existence. Speaking of point, the most basic existential state and its characters of are worthy of analyzing.

According to Heidegger, the most basic existential state of human beings is the being-in-the-world. As being-in-theworld, human beings not merely have a strong inclination to be ensnared in entities within the world of their circumspective concern in a way in which they can be definite in finding out a fact that who they are is determined by those entities through interpreting themselves in terms of the world of their concern - an ontological light of being in which they concernfully exist. Human beings are also ensnared in historical tradition and socially constructed normative standards with which they are shaped, characterized, and managed. Tradition and socially constructed normative standards largely and constantly deprive human beings of their leadership in the acts of questioning and making-decision. This is true of human beings' understanding of being which is co-original with being-in-the-world - the being-ontological human beings (EB, 56), which is tend to be characterized by the publicness in which human beings are fatefully thrown. This publicness of the world is what human beings in their everyday existence look for, because it is the whence (provenance) of the feeling of "being-at-home" in the world. How does this publicness in which human beings find "beingat-home” come into being? To investigate into the existential root we must trace back to the primordiality of the human being; to the very conditions of possibility of understanding of being; to the very facticity of human beings' "falling" which "is a definite existential characteristic of Dasein itself” (BT, 220).

Being-in-the-world is a unitary phenomenon which is primordially and constantly the whole story of human beings; but "Being-in-the-world is always fallen" (BT, 225). “Accordingly, Dasein's ‘average everydayness' can be defined as Being-in-the-world which is falling and disclosed, thrown and projecting, and for which its ownmost potentiality-for-Being is an issue, both in its Being alongside the 'world' and in its Being-with Others" (ibid). Human beings as being-in-the-world result in their being-thrownness primordially. Although this being-thrownness means neither being-finished nor being-settled once for all, it provides human beings with a definite and primordial intelligible framework within which the act of understanding and interpretation can set in motion. This intelligible framework is none other than the worldhood of the world which is cooriginal with being-in-the-world and characterized by a system of significance. Therefore, the publicness of the world into which human beings are thrown must express itself with and through this system of significance. Consequently, when a human being is being-with others, at least part of his worldhood of the world will be existentially-ontologically shared by others in a world all of them live. This sharedness is what we call publicness. With this publicness, people in the world will have opportunities to share or understand each other. This publicness is not an entity; it is the kind of understanding of being. It exists in nowhere but an understanding of being. It is fit for the relationship between that which translates and what is going to be translated, too. Not only that. It is the only bridge that can get through that which translates and what is going to be translated; in other words, it is the premise for the possibility of the act of translation.

Evidently, the phenomenon of faithfulness in translation is such a being-manifest of phenomenon of publicness which first of all emerges in an understanding of being of the translator; with and through this understanding of being, the translator comports himself/herself towards that which is going to be translated in a way in which that which is going to be translated can show itself from itself. Only when such publicness emerges between the translator and that which is going to be translated can the translator be able to translate. Only when that which is going to be translated becomes what it is in itself in the translator's understanding of being in terms of publicness, can that which is going to be translated be translated. Publicness, that is, the common worldhood of the world, or the shared world of significance, is equiprimordial with faithfulness which is the inherent requirement of the understanding of being or being-in-the-world that is the existential-ontological presupposition of the act of translation. The existential-ontological ground for the act of translation which is inseparable from publicness and faithfulness is that any act of translation as the act of understanding of being must be affirmed as it is not only by the world which has been understood and shared by human beings but also by the very fact of human beings' understanding of being of the entities within the world; otherwise there will be no necessary act of translation and understanding of being, because, on Heidegger view, "The being of the kind of 'Dasein' is in its Being concerns about its Being and behaves towards its Being as towards its own possibility" (EB, 28), or "That entity which in its Being has this very Being as an issue, comports itself towards its Being as its ownmost possibility". "Dasein is an entity which, in its very Being, comports itself understandingly towards that Being” (BT, 68/78). And this 
kind of being, for the purpose of achieving self-definition, must engage other being: "Existence in history, the claim to recognizable identity, are based on relations to other articulate constructs” (Steiner, 2004: 317). That is to say, when there is the act of understanding of being as well as the act of translation, there must be the kind of being of entities which in every case corresponds with the kind of being of human beings' understanding of being. To put it simply, it is the understanding of being that determines the kind of being of entities, and therefore entities within the being-discovered world can only be as disclosed as such-and-such in terms of the human being. In this kind of human being, publicness and faithfulness both play the role of attesting to the being.

Although the conception "faithfulness" in the history of translation appeared in China is more than two thousand years later than that in the West, there is still a common suggestion that to this conception was first given rise at the time when the act of translation as a movement came into its boom respectively in China and in the West (Wang Dongfeng, 2004: 3). But no matter wherefrom the act of translation takes place, the being of the translator's being-alongside that which is to be translated is an irrefutable fact. Being-alongside that which is to be translated means nothing more than the translator's being is being in deseverance with that which is to be translated. Deseverance presupposes distantiality. But distantiality which belongs to the being-alongside is that which the translator, as the everyday being-alongside that which is to be translated, stands in subjection to Others (here the "Others" is another term for publicness which is mainly constitutive for the world, and that which is to be translated is undoubtedly the entities ready-to-hand within-the-world to which the translator comports himself/herself). The translator who is in the world of significant relations cannot perform the act of translation completely at his/her own disposal, because such a world in which he/she lives has already been socially constituted, normatively standardized, and historicallytraditionally chartered before he/she is thrown and projects the understanding of being. This world, on Heidegger view, mainly plays the role of Others or Publicness. What does the role of Others play in our everyday existence which of course includes the act of translation? The Others, by reason of its definitive character of publicness, has the power or even the responsibility of taking away the right of the translator's understanding of being. The translator's possibilities of understanding of being to be projected upon entities are for the Others to dispose of as it pleases. Those individuals who are the constitutive items of the Others, moreover, are not definite by all means in character. On the contrary, any one of the Others can represent the Others. What is decisive is just the inconspicuous and anonymous domination occupied by the Others which has already taken over unawares from the translator as being-alongside with entities within the world. Any individual translator belongs himself/herself to the Others and hence enhances the power of the Others. The Others to "which" the translator is thus assigned in order to cover up the fact that it has already had the translator into its embrace is essentially the translator himself/herself. Consequently, it is the Others instead of the translator that are those "which" in the Others proximally and for the most part are there in the everyday being-alongside entities within the world. Here, the "which" to which the translator belongs is not this one, not that one, not itself, not the translator, not the sum of them. The "which" is the neuter, the publicness, the shared worldliness (to be continued).

\section{References}

[1] Culler, Jonathan. On Deconstruction: Theory and Criticism after Structuralism. Beijing: Foreign Language Teaching and Research Press, 2004.

[2] Derrida, Jacques. Writing and Differences. Alan Bass (trans.) Britain: Routledge and Kegan Paul Ltd., 1978.

[3] Derrida, Jacques. "Living On: Border Lines." In Bloom et al., Deconstruction and Criticism. New York: Seabury, 1979.

[4] Derrida, Jacques. Margins of Philosophy. Alan Bass. (trans.) Chicago: The University of Chicago Press, 1982.

[5] Derrida, Jacques. Positions. Alan Bass. Trans. Chicago: The University of Chicago Press, 1981.

[6] Fletcher, W. Gems of Chinese Verse. Shanghai: The Commercial Press, 1935.

[7] Ferraris, Maurizio. History of Hermeneutics, Luca Somigli (trans.) New Jersey: Humanities Press, 1996.

[8] Gutt, Ernst-August. Translation and Relevance-Cognition and Context. Shanghai: Shanghai Foreign Language Education Press, 2004.

[9] Heidegger, Martin. Kant and the Problem of Metaphysics. R. Taft (trans.) Bloomington: Indiana University Press, 1990.

[10] Heidegger, Martin. Nietzsche, vol. I: The Will to Power as Art. D. F. Krell (trans.) London: Routledge \& Kegan Paul, 1981.

[11] Heidegger, Martin. Nietzsche, vol. II: The Eternal Recurrence of the Same. D. F. Krell (trans.) San Francisco: Harper \& Row, 1984.

[12] Heidegger, Martin. Nietzsche, vol. III: The Will to Power as Knowledge and as Metaphysics. J. Stambaugh, D. F. Krell, F. A. Capuzzi (trans.) San Francisco: Harper \& Row, 1987.

[13] Heidegger, Martin. Nietzsche, vol. IV: Nihilism. F. A. Capuzzi (trans.) San Francisco: Harper \& Row, 1982. 